IZA DP No. 47

Tenure-based Wage Setting

Robert A. Hart

Felix Ritchie

J uly 1999 


\title{
Tenure-based Wage Setting
}

\author{
Robert A. Hart \\ Felix Ritchie
}
Discussion Paper No. 47
July 1999

\author{
IZA \\ P.O. Box 7240 \\ D-53072 Bonn \\ Germany \\ Tel.: +49-228-3894-0 \\ Fax: +49-228-3894-210 \\ Email: iza@iza.org
}

This Discussion Paper is issued within the framework of IZA's research areas Mobility and Flexibility of Labor Markets and General Labor Economics. Any opinions expressed here are those of the author(s) and not those of the institute. Research disseminated by IZA may include views on policy, but the institute itself takes no institutional policy positions.

The Institute for the Study of Labor (IZA) in Bonn is a local and virtual international research center and a place of communication between science, politics and business. IZA is an independent, nonprofit limited liability company (Gesellschaft mit beschränkter Haftung) supported by the Deutsche Post AG. The center is associated with the University of Bonn and offers a stimulating research environment through its research networks, research support, and visitors and doctoral programs. IZA engages in (i) original and internationally competitive research in all fields of labor economics, (ii) development of policy concepts, and (iii) dissemination of research results and concepts to the interested public. The current research program deals with (1) mobility and flexibility of labor markets, (2) internationalization of labor markets and European integration, (3) the welfare state and labor markets, (4) labor markets in transition, (5) the future of work, and (6) general labor economics.

IZA Discussion Papers often represent preliminary work and are circulated to encourage discussion. Citation of such a paper should account for its provisional character. 
IZA Discussion Paper No. 47

July 1999

\section{ABSTRACT}

\section{Tenure-based Wage Setting}

We provide empirical support for the contention that within-job wage growth relates purely to job-specific performance and that returns to general experience are assessed at the point of job change. Using the British New Earnings Survey panel data we identify job changes that take place both within and between firms. We follow a cohort of 6778 male workers (born between 1958 and 1962) for the period 1975 to 1994 and estimate their within-job wage changes by allowing returns to vary over jobs. Between job changes are observed for individuals changing jobs in 1994. This work leads us to question the meaningfulness of attempts to separate returns to general and firm-specific human capital.

JEL Classification: J3, J6

Keywords: Tenure, experience, earnings, panel data

Robert A. Hart

Department of Economics

University of Stirling

Stirling FK9 4LA

Scotland, U.K.

Tel: +4401786467471

Fax: +441786467469

e-mail: r.a.hart@stir.ac.uk 


\section{Introduction}

The process of assessing the value of a "typical" worker's general human capital involves significant money and time costs. Such costs would be expected to rise through time as experience accumulates over several jobs, with some job changes taking place between firms and others involving quite different task specifications within the same firm. As career paths lengthen, evaluating the worth of general capital will increasingly require supporting evidence; this may include (a) testimonies of previous employers and work colleagues, (b) a curriculum vita, (c) confirmation of formal recognition of work-related achievements, (d) records of general educational and job-related qualifications attained during labour force participation, (e) direct interviews. Rather than updating and re-evaluating this information on a continual basis, it may be more efficient to take stock of progress at discrete time intervals. A natural time to undertake this work is when firms select among candidates to fill job vacancies or when employees apply for promotion.

In the developments that follow, we separate wage changes into those that occur between jobs and those within jobs. We conjecture that wage changes between jobs result from re-evaluations of career-long accumulation of general skills and know-how. By contrast, wage changes within jobs are geared to job-specific performance. Such changes represent returns to acquired general and specific skills on the job. This combined process is efficient for three reasons. First, it simplifies the process of individual performance-assessment, and thereby reduces the cost, in that it limits the number of time points at which the value of general labour market experience is evaluated. Second, it provides scale economies since the processes of filling job vacancies or assessing promotions often involve groups of individuals whose general 
aptitudes are evaluated and compared at a single time period. Third, it simplifies within-job wage assessment by limiting consideration to the execution of tasks within single jobs.

Testing these arguments requires that we account empirically for job changes that take place between firms or within existing firms. Promotion processes that lead to withinor between- firm job changes are highly interrelated; both external and internal candidates may compete for the same job. Where job changes involve mainly internal promotions (and demotions), then assessment appears often to take place at discrete time points, selecting who will and who will not proceed to more senior job positions. With exceptions, this view tends to be supported by career-tree studies that track the career progressions of cohorts of individuals during given time periods. ${ }^{1}$

Our empirical methodology involves modelling job effects on wages to allow estimated returns within jobs to vary over jobs. This admits more generality into the mobility decision. One partial reason for changing jobs is that an individual may make the short-term gain of a positive wage increment (net of transactions costs) in the new compared to the old job. But this is neither a sufficient nor a necessary condition for a job move. The full motivation encompasses not only the size of the initial wage increment but also the relative shapes of wage profiles, actual and expected, between successive jobs. A job mover may be induced to move with no initial wage increase if the expected wage accumulation by length of tenure is deemed to be more favourable over some relevant discount period.

\footnotetext{
${ }^{1}$ In line with the pioneering work of Rosenbaum (1979), these studies tend to support tournament-style patterns of job promotions.
} 
Our data source is the UK New Earnings Survey (NES) panel data. Data are establishment-based, being derived from employers' payroll tax records. We concentrate on full-time male workers. We have records on 6778 individuals who were born between 1958 and 1962. For our within-job estimation, we follow five age cohorts of 5848 individuals from 1975 to 1994, all of whom were in the same job in 1993-4. Our between-job estimation is based on 930 individuals who changed jobs in 1994.

\section{Job changes and the evaluation of general and job-specific skills}

We purposely refer to job changes in a quite general sense. These might occur within or between firms. Both intra- and inter-firm job moves may involve (a) an evaluation by one or more parties of relative inside and outside job opportunities and (b) competition and selection among internal and external candidates.

Imagine a 'typical' individual who leaves school and is promoted through a succession of jobs of varying job lengths. Each new job involves more complexity, greater independent decision making, and wider responsibilities. Promotion to a new job represents an actual or potential wage gain in that the individual is raised to a higherlevel wage path belonging to a more senior job and/or attains a steeper wage profile. Each promotion is predicated on a positive outcome from a selection procedure. Job promotions sometimes take place within a given firm and sometimes through changing firms. Within any given job, there is a rising wage profile that reflects increasing proficiency in the execution of that job. How are returns to general work experience and job-related experience likely to be reflected on the individual's wage progression 
through time? There are many possibilities, but we propose that the most logical is one that is not captured in the various representations of the Mincer equation.

It is likely that, in large part, returns to accumulated general labour market experience are reflected in the wage growth path in two separate ways. First, a rising wage path within each job reflects the acquisition of general and specific skills and know-how associated with the job itself. Moreover, within-job wage growth occurs independently of the past history of accumulated general experience. Second, at the point of job change, wage adjustments reflect additions to general labour market experience acquired in the last job together with a re-assessment of the career-length accumulation of general skills.

The reasoning is simple. Beyond the individual's first job appointment, it is increasingly unlikely that peer-group assessments of total labour market experience that is from completion of pre-work education to the current age of the individual - are continually revised and reflected in wage paths within given jobs. The relatively high costs of such evaluations are unlikely to be regularly incurred. Rather, time and effort are more likely to be devoted towards judging the worth of an individual's overall general skills at the selection stage of a new job. Further, as work histories become increasingly complex through time, understanding an individual's progress is likely to involve measurement of performance relative to comparable career paths.

These types of consideration form the important substance of job selection from a group of job applicants. A positive wage increment between the old and new job resulting from a successful job application reflects a view by the assessors that an adjusted return to general experience is warranted in the light of a retrospective view 
of career progress in respect of general human capital acquisition. In many instances, wage adjustments between-jobs may be very minor. This would reflect a view of both workers and assessors that the evaluated worth of general human capital at the start of the previous job, together with payment for general accumulation on the previous job, were reflective of actual achievement. In these instances, only minor fine-tuning would be required to place individuals at the 'correct' positions on their career wage profiles.

Where a job change takes place, the selection process serves, in effect, to wind back the general experience clock to zero and wage progression within the new job is predicated only on work performance that is strictly related to the additional direct and indirect demands of that job. This is an efficient organisation of resources because within-job assessment and monitoring can be concentrated on value added on-the-job and uncluttered by regard to background performances in earlier jobs.

Consider the representation in Figure 1 of an individual's wage profile pertaining to the first two firms since after leaving full-time education. By time $t$, the individual has held four jobs, two in Firm 1 and two in Firm 2. The four periods of job tenure, $T_{i}(i=$ $1, . .4)$, include an incomplete spell, $\mathrm{T}_{4}$. Three wage gains have occurred at the point of job change. Suppose, as conjectured, that these wage gains represent adjustments to re-evaluations of general human capital while wage gains within jobs are due to jobspecific performance. What would be the combined consequences of (a) accounting only for inter-firm job changes, (b) not allowing returns to vary over jobs, and (c) measuring general human capital within jobs in terms of career-length accumulated experience? Here, we highlight four potential problems. 
(1) The individual in Figure 1 would be observed "as if" one job has been undertaken in each firm; that is 0 - B and B - D. There would be no way of discriminating between intra-firm wage rises due to job changes and movements along the two profiles: i.e. the profiles 0 to A, A to B and the intervening wage increase.

(2) There would be no meaningful measurement of the relative steepness of wage profiles over an individual's career since there would be no knowledge of numbers intra-firm separate job profiles.

(3) For a cohort of individuals entering a firm at a given time period, suppose that subsequent job promotion within the firm involves successively smaller proportions of the cohort (see Rosenbaum 1979). Then, the shapes of profiles based purely on inter-firm data will be biased towards the intra-firm profiles of workers with the weakest promotion performances.

(4) Omitting intra-firm changes make it appear that returns to general and specific investment can be meaningfully separately identified. This is represented in Firm 2 at time $t$ by the fact that the tenure line $\mathrm{B}-\mathrm{D}$ differs in slope from the general experience line $0-\mathrm{D}$. By contrast, we argue that returns to general and specific experience during $T_{3}$ in job 3 and $T_{4}$ in job 4 - as well as between all other jobs cannot be separately identified. Returns within a given job relate solely to that job and reflect both general and specific on-the-job gains. Only between jobs are career-length general labour market returns assessed. 


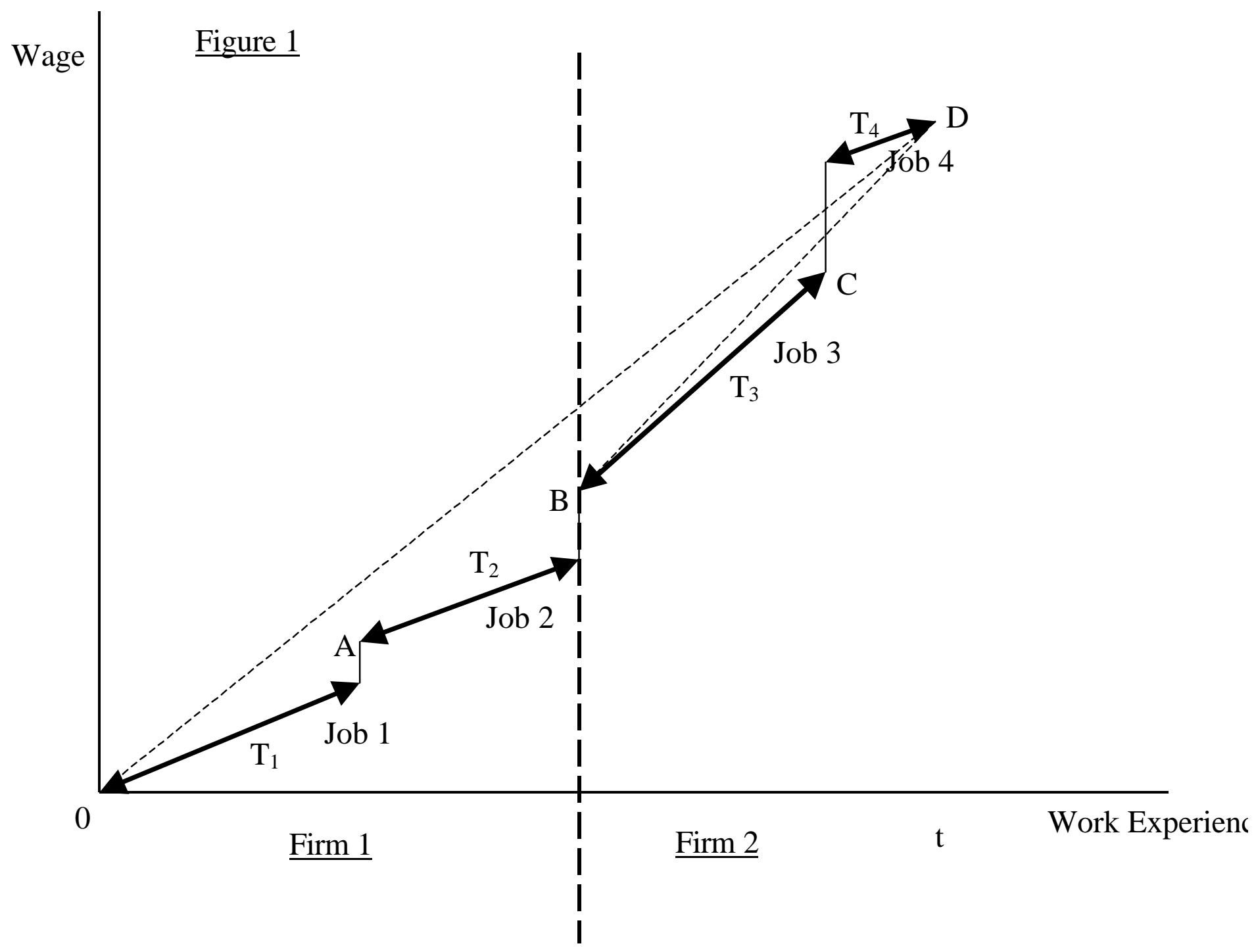




\section{Data and panel structure}

We use the British NES panel survey for the years 1975 to 1994 . The NES meets our essential requirement that we can identify all job changes. A job change is coded whether or not it takes effect between firms or within the existing firm. ${ }^{2}$ Based on employers' payrolls, the NES does not record individuals' education and schooling. We obtained our measure of experience in the following manner. We concentrated attention on five cohorts of individuals born each year from 1958 to 1962. Members of each cohort were observed "entering" the NES in seven age groups; these were the ages of 17, 18, 19, 20, 21, 22 and 23 and above. Those entering at the youngest age would have received the minimum level of compulsory education in Britain while successively older age groups would typically coincide with higher levels of pre-work education and training. ${ }^{3}$ Once an individual enters the NES, it is possible to measure work experience directly as the number of years during which they have appeared on company payrolls. In other words, we can subtract numbers of years of unemployment. This direct measure of work experience has an advantage compared to the most commonly adopted measures - such as age minus years of schooling minus pre-school years - which do not discount absences from the labour force.

Our five cohorts gave us complete records on 6778 individuals. An individual's firm status in 1994, the last date of available data, was used as the basis for constructing the data sets. Of this total, 5848 individuals were in the same job in 1994 as in the

\footnotetext{
${ }^{2}$ Although the data do not allow us to identify whether or not a given job change took place within single firm or between firms.

${ }^{3}$ Unfortunately, we were not able to identify those in the post-17 age groups who had undergone a spell of time during which they received no education and no work experience prior to appearing in the NES.
} 
previous year and they form our within-job sample. (Of this sample in 1994, 19\% were still in job 1, 27\% in job 2, and so on - see Table 1.) The remaining 930 individuals changed jobs between 1993 and 1994 and we base our between-job estimates on these. Tests for differences between cohorts - viz. F-tests on the restriction that the coefficients were the same across all cohorts - proved insignificant. Similar tests were undertaken with respect to "education groups" and again we found no differences. We therefore combined the cohorts and educational groups for estimation purposes.

We carry out within- and between- job estimation following the methodological approach suggested by Topel (1991). There is a key difference, however. Topel uses the two-step procedure in order to identify two elements of the same model while our framework identifies two models. The next two sections report, respectively, our findings with respect to these two job divisions.

\section{Within-job earnings}

We begin by concentrating on the earnings-experience relationships within jobs. Beyond allowing returns to vary over jobs, we specify a standard form of Mincer equation. The model is based on a linear relationship between earnings and experience for individual $\mathrm{i}$ on job $\mathrm{j}$ at time $\mathrm{t}$ :

$$
y_{i j t}=X_{i j t} \beta_{j 1}+T_{i j t} \beta_{j 2}+\mu_{i}+\phi_{i j}+\eta_{i j t}
$$

where $\mathrm{y}_{\mathrm{ijt}}$ is $(\log )$ earnings, $\mathrm{X}_{\mathrm{ijt}}$ is "general" experience, $\mathrm{T}_{\mathrm{ijt}}$ is "job-specific" experience, $\mu_{\mathrm{i}}$ is individual-specific heterogeneity in wages, $\phi_{\mathrm{ij}}$ is a "job-effect" assumed constant for that individual-job-employer combination, and $\eta_{\mathrm{ijt}}$ represents other job-matching. The $\beta_{\mathrm{j}}$ coefficients allow returns to vary over jobs. General experience is measured as 
the number of years in employment since an individual from our 1958-62 cohorts first appeared in our sample. Following the discussion of the previous sections, our maintained hypothesis is $\beta_{j 1}=0$.

Assuming experience (both general and specific) increments by one each period, so $\mathrm{X}_{\mathrm{t}}$ $\equiv \mathrm{X}_{0}+\mathrm{T}_{\mathrm{t}}$, we rewrite (1) and (2) as

$$
y_{i j t}=X_{0 i j} \beta_{j 1}+T_{i j t}\left(\beta_{j 1}+\beta_{j 2}\right)+\varepsilon_{i j t}
$$

where $\varepsilon_{\mathrm{ijt}}=\mu_{\mathrm{i}}+\phi_{\mathrm{ij}}+\eta_{\mathrm{ijt}}$.

Differencing (3) yields

$$
\Delta \mathrm{y}_{\mathrm{ijt}}=\beta_{\mathrm{j} 1}+\beta_{\mathrm{j} 2}+\Delta \eta_{i j t}
$$

The fixed job-effect drops out when differencing within jobs. OLS estimates of the coefficients in (3) are unbiased if $\mathrm{E}\left(\Delta \eta_{\mathrm{ijt}}\right)=0$.

Table 1 presents OLS estimates of wage growth within jobs (equation 3). Following arguments by Murphy and Welch (1990) and others, we use quartic specifications of the job-tenure and general labour market experience variables. Separate within-job estimates are shown with respect to each of the first four jobs held by members of the cohorts while results for job 5 and above are aggregated.

This specification of equation (3) is rejected. In particular, there are no cases of significant general experience effects in any of the five job demarcations. ${ }^{4}$ In the lower

\footnotetext{
${ }^{4}$ Strictly speaking, we cannot completely dismiss the role of general experience because we cannot test for the significance of the linear first-differenced term. But a simple linear relationship between earnings and experience growth is highly unlikely on a priori grounds.
} 
half on the table, we present our preferred specification. Only job tenure is included,

which we contend represents accumulations of both general and specific capital on-thejob. The model here provides altogether more satisfactory results. Removing the general experience variables has the effect - with the exception of job 1 where the two models coincide - of producing generally well estimated returns to on-the-job experience. Plots of the wage-tenure profiles to this second specification over a tenyear period are displayed in Table 2 with corresponding graphs shown in Figure 2.

Table 1 Within-job wage growth 1974-1994 (1958-62 age cohorts)

(Dependent variable is change in log of real wage)

\begin{tabular}{|c|c|c|c|c|c|c|c|}
\hline $\begin{array}{l}\text { Job (\% of } \\
\text { sample) }\end{array}$ & $\Delta \mathbf{T}$ & $\begin{array}{c}\Delta \mathbf{T}^{\mathbf{2}} \\
\left(\times 10^{2}\right)\end{array}$ & $\begin{array}{c}\Delta \mathbf{T}^{\mathbf{3}} \\
\left(\times 10^{3}\right)\end{array}$ & $\begin{array}{c}\Delta \mathbf{T}^{4} \\
\left(\times 10^{4}\right)\end{array}$ & $\begin{array}{c}\Delta \mathbf{X}^{2} \\
\left(\times 10^{2}\right)\end{array}$ & $\begin{array}{c}\Delta \mathbf{X}^{\mathbf{3}} \\
\left(\times 10^{3}\right)\end{array}$ & $\begin{array}{c}\Delta \mathbf{X}^{4} \\
\left(\times 10^{4}\right)\end{array}$ \\
\hline 1 (19) & $\begin{array}{l}0.086 * \\
(0.020)\end{array}$ & $\begin{array}{c}-0.015^{*} \\
(0.004)\end{array}$ & $\begin{array}{l}0.010 * \\
(0.003)\end{array}$ & $\begin{array}{l}-0.002 * \\
(0.001)\end{array}$ & N/A§ & N/A§ & N/A $\S$ \\
\hline 2 (27) & $\begin{array}{c}0.0 \\
(0.045)\end{array}$ & $\begin{array}{c}-0.009 * \\
(0.004)\end{array}$ & $\begin{array}{l}0.009 * \\
(0.003)\end{array}$ & $\begin{array}{c}-0.003 * \\
(0.001)\end{array}$ & $\begin{array}{c}0.005 \\
(0.007)\end{array}$ & $\begin{array}{l}-0.002 \\
(0.005)\end{array}$ & $\begin{array}{c}0.0 \\
(0.001)\end{array}$ \\
\hline 3 (23) & $\begin{array}{c}0.048 \\
(0.090)\end{array}$ & $\begin{array}{c}-0.003 \\
(0.004)\end{array}$ & $\begin{array}{c}0.003 \\
(0.004)\end{array}$ & $\begin{array}{l}-0.002 \\
(0.002)\end{array}$ & $\begin{array}{l}-0.002 \\
(0.012)\end{array}$ & $\begin{array}{c}0.0 \\
(0.007)\end{array}$ & $\begin{array}{c}0.0 \\
(0.001)\end{array}$ \\
\hline $4 \quad(16)$ & $\begin{array}{c}0.138 \\
(0.159)\end{array}$ & $\begin{array}{c}-0.014 * \\
(0.004)\end{array}$ & $\begin{array}{l}0.021 * \\
(0.006)\end{array}$ & $\begin{array}{c}-0.009 * \\
(0.006)\end{array}$ & $\begin{array}{l}-0.009 \\
(0.020)\end{array}$ & $\begin{array}{c}0.003 \\
(0.011)\end{array}$ & $\begin{array}{c}-0.0 \\
(0.002)\end{array}$ \\
\hline $5+(16)$ & $\begin{array}{c}0.198 \\
(0.247)\end{array}$ & $\begin{array}{l}-0.006 \\
(0.005)\end{array}$ & $\begin{array}{c}0.004 \\
(0.008)\end{array}$ & $\begin{array}{l}-0.001 \\
(0.004)\end{array}$ & $\begin{array}{c}-0.018 \\
(0.029)\end{array}$ & $\begin{array}{c}0.009 \\
(0.015)\end{array}$ & $\begin{array}{l}-0.002 \\
(0.003)\end{array}$ \\
\hline 1 & $\begin{array}{l}0.086 * \\
(0.020)\end{array}$ & $\begin{array}{c}-0.015 * \\
(0.004)\end{array}$ & $\begin{array}{l}0.010 * \\
(0.003)\end{array}$ & $\begin{array}{l}-0.002 * \\
(0.001)\end{array}$ & - & - & - \\
\hline 2 & $\begin{array}{l}0.035 * \\
(0.012)\end{array}$ & $\begin{array}{c}-0.008 * \\
(0.003)\end{array}$ & $\begin{array}{l}0.008 * \\
(0.003)\end{array}$ & $\begin{array}{c}-0.002 * \\
(0.001)\end{array}$ & - & - & - \\
\hline 3 & $\begin{array}{l}0.029 * \\
(0.012)\end{array}$ & $\begin{array}{c}-0.003 \\
(0.004)\end{array}$ & $\begin{array}{c}0.003 \\
(0.004)\end{array}$ & $\begin{array}{l}-0.001 \\
(0.002)\end{array}$ & - & - & - \\
\hline 4 & $\begin{array}{l}0.039 * \\
(0.012)\end{array}$ & $\begin{array}{c}-0.014 * \\
(0.004)\end{array}$ & $\begin{array}{l}0.021 * \\
(0.005)\end{array}$ & $\begin{array}{c}-0.009 * \\
(0.002)\end{array}$ & - & - & - \\
\hline $5+$ & $\begin{array}{l}0.041 * \\
(0.011)\end{array}$ & $\begin{array}{c}-0.006 \\
(0.005)\end{array}$ & $\begin{array}{c}0.004 \\
(0.008)\end{array}$ & $\begin{array}{c}-0.001 \\
(0.004)\end{array}$ & - & - & - \\
\hline
\end{tabular}

Notes: Standard errors in parentheses. Total sample consists of 5848 individuals. * Significant at $5 \%$ level. $\S$ Differenced tenure and experience are the same in job1. 
Figure 2: Returns to within-job experience

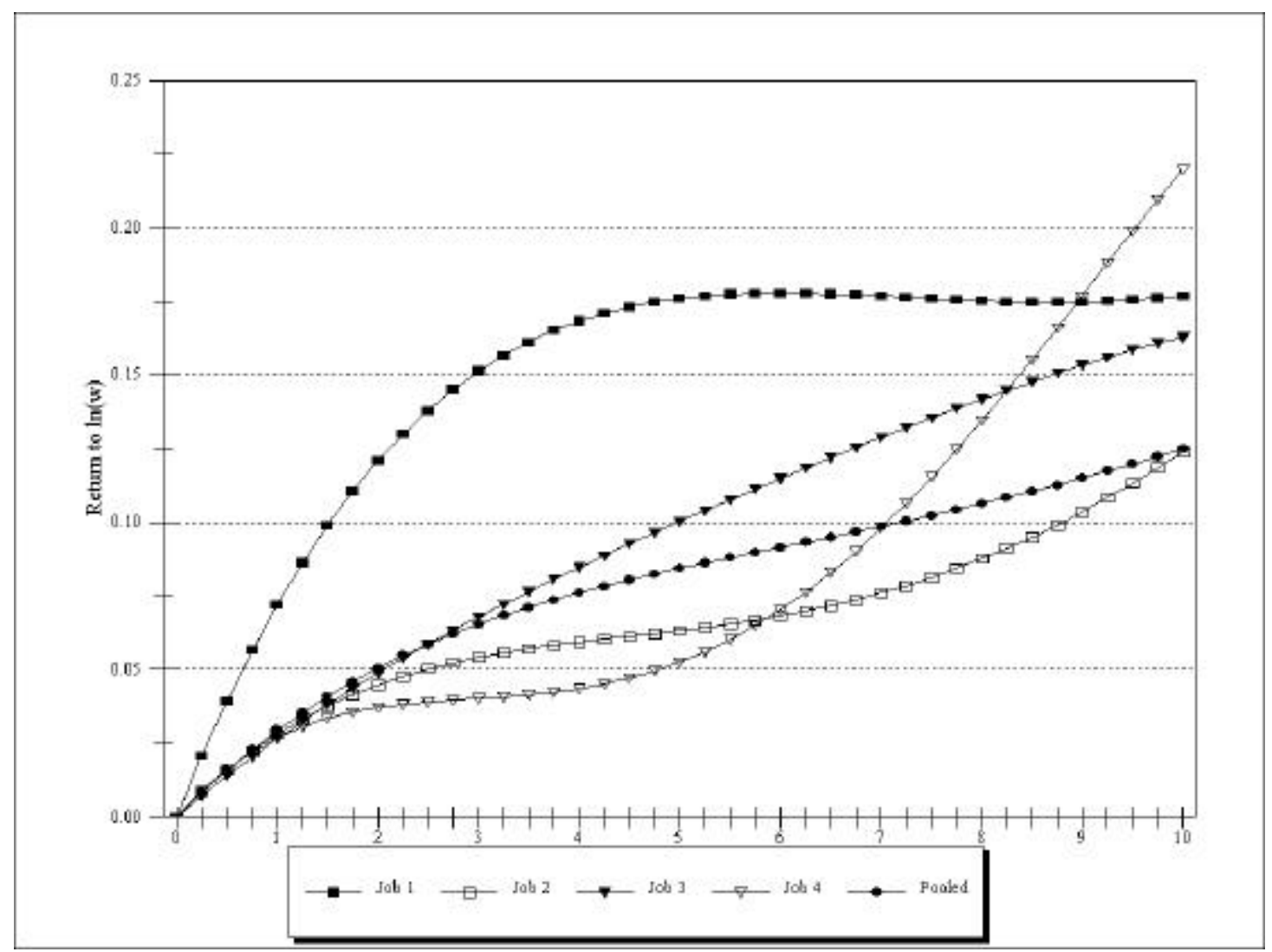

Table 2 Predicted within-job wage growth by years of job tenure

\begin{tabular}{l|cccccccccc}
\hline & \multicolumn{10}{|c}{ Tenure } \\
\cline { 2 - 11 } Job & 1 & 2 & 3 & 4 & 5 & 6 & 7 & 8 & 9 & 10 \\
1 & 0.072 & 0.121 & 0.151 & 0.168 & 0.176 & 0.178 & 0.177 & 0.175 & 0.175 & 0.177 \\
2 & 0.028 & 0.045 & 0.054 & 0.059 & 0.063 & 0.068 & 0.076 & 0.088 & 0.104 & 0.124 \\
3 & 0.027 & 0.049 & 0.068 & 0.085 & 0.100 & 0.115 & 0.129 & 0.142 & 0.153 & 0.163 \\
4 & 0.027 & 0.037 & 0.040 & 0.044 & 0.053 & 0.070 & 0.098 & 0.135 & 0.177 & 0.220 \\
$5+$ & 0.035 & 0.059 & 0.076 & 0.086 & 0.092 & 0.096 & 0.098 & 0.100 & 0.103 & 0.107 \\
\hline "Pooled" & 0.029 & 0.050 & 0.065 & 0.076 & 0.084 & 0.092 & 0.099 & 0.106 & 0.115 & 0.125 \\
\hline
\end{tabular}

It is evident from Figure 2 that there is steep wage growth during the early years of job

1 followed by a marked levelling-off in the profile thereafter. This is a plausible

outcome and may well represent the rapid acquisition of skills in a job of limited wage

growth potential. Later jobs display progressively rising wages over the ten-years, 
albeit with different profile trajectories across jobs. The 'pooled' estimates are derived by not distinguishing between returns within individual jobs.

As a final ad hoc test, we also carried out the regressions shown in Table 1 for the case where tenure is suppressed and only general experience included. Apart from Job1 which is identical to the first regression in the lower half of the table because tenure and general experience in this job are identical - we obtained no cases of significant coefficients.

In summary, we find no evidence whatsoever that general labour market experience is reflected in the within-job profiles.

\section{Between-job earnings}

From the within-job analysis, we conclude that $\beta_{j 1}=0$ in (1) and that $\beta_{j 2}$ represents the combined general and specific returns to job j. However, we argue that general experience is evaluated at the appointment stage of a new job and a wage adjustment may be made in respect of an assessment of the career accumulation of general experience. This effect is captured by the job-effect term, $\phi_{\mathrm{ij}}$, in (1), although we may express it more directly as

$$
\phi_{\mathrm{ij}}=\mathrm{X}_{0 \mathrm{ij}} \beta_{3}+\delta_{\mathrm{ij}}
$$

where $X_{0}$ is initial experience on the job, $\beta_{3}$ is the return to general experience at the evaluation stage, and $\delta_{\mathrm{ij}}$ are remaining job effects.

Imposing $\beta_{j 1}=0$ in (2) and using (4) gives 


$$
y_{i j t}=X_{0 i j} \beta_{3}+T_{i j t} \beta_{j 2}+\mu_{i}+\delta_{i j}+\eta_{i j t} .
$$

It is clear from (4) that, with respect to new jobs, fixed effects cannot be identified from $\mathrm{X}_{0 \mathrm{ij}}$ within a job $\mathrm{j} .{ }^{5}$ However, we may usefully re-formulate (5) as:

$$
y_{o i j t}=X_{0 i j} \beta_{3}+T_{i j t} \beta_{j 2}+\mu_{i}+\delta_{j}+\gamma_{i j}+\eta_{i j t}
$$

where $\gamma_{i j} \equiv \delta_{i j}-\delta_{j}$.

The interpretation of this formulation is that there is a common job match effect across all firms as well as a specific firm-related effect. The relevance of (6) arises when we consider differencing earnings across new jobs. Consider two jobs $\mathrm{j}$ and $\mathrm{k}=\mathrm{j}-1$. When both are new (ie $\mathrm{T}_{0 \mathrm{ij}}=\mathrm{T}_{0 \mathrm{ik}}=0$ ) we have

$$
\begin{aligned}
y_{0 i j}-y_{o i k} & =\left(X_{o i j}-X_{0 i k}\right) \beta_{3}+\delta_{j}-\delta_{k}+\gamma_{i j}-\gamma_{i k}+\eta_{0 i j}-\eta_{0 i k} \\
& =T_{i k T} \beta_{3}+\left(\delta_{j}-\delta_{k}\right)+\left(\delta_{i j}-\delta_{j}\right)-\left(\delta_{i k}-\delta_{k}\right)+\eta_{o i j}-\eta_{o i k}
\end{aligned}
$$

\footnotetext{
${ }^{5}$ It might be argued that the returns to general experience in (4) might also be allowed to vary over jobs to reflect the relative efficiencies of job matches. However, in our framework, $T$ refers to job specific experience and we argue that it accounts for both changes in returns to general and specific knowledge on-the-job. In other words, changing returns to general experience cannot be identified separately from changing returns to tenure. In any event, from a labour market perspective, changing coefficients on general experience over jobs is not particularly convincing. We have argued that general experience is assessed periodically, at the point of potential job change, and then agreeing a growth path for the new job, which may vary over time because both general and specific experience vary over time. For a firm to consider changing the slope of the returns to experience involves calculating the "true" slope for an individual. Where information is costly, it makes more sense when making a one-off hiring decision to place the individual at an appropriate point on a "representative" general experience path before introducing person-specific monitoring and reporting in order to determine within-wage growth solely in terms of on-the-job performance.
} 
where $T_{i k T}$ is the number of years spent on job k.

Equation (7) has removed bias due to correlation between individual "ability" and experience, but job-effects remain. This will still bias estimates of $\beta_{3}$ if the differenced job-effects are correlated with tenure, which seems likely. In general, a 'good' job match is likely to be associated with long tenure, in which case we might expect a positive association between $\mathrm{T}_{\mathrm{ikT}}$ and $\delta_{i k}$. It is perhaps more difficult to infer a systematic pattern of association between $\mathrm{T}_{\mathrm{ikT}}$ and $\delta_{i j}$, however. Our approach to estimating (7) is to instrument the tenure variable. We use age as an instrument. ${ }^{6}$ In the first place, we would expect age to correlate positively with length of tenure. Significant differences in individual ability may weaken this expectation - e.g. highfliers might have shorter tenure at every age - but, by differencing the model, we have taken out such heterogeneity. In the second place, age and job match would be expected to be independent given our estimation procedures. Note that the difference $\gamma_{i j}-\gamma_{i k}$ in (7) represents the mean difference in wages relative to other workers in each successive new job compared to the previous job. Since we have taken out group mean effects by including job dummies and individual effects by differencing, there is no reason to suppose other than age would be independent of job match.

Both OLS and IV estimates of equation (7) are presented in Table 3. The experience variables enter with the expected signs. While there appear to be no systematic patterns in the job dummy variables, several of these are significant. Comparisons of

\footnotetext{
${ }^{6}$ We note that Dustmann and Meghir (1998) also support the notion, although in a somewhat different context, that age is an appropriate instrument for experience.
} 
both OLS and IV estimates with and without job dummies reveals that including dummies enhances overall equation performances. In the case of the IV estimates, Figure 3 shows the estimated profiles with and without job dummies. From these graphs, it is clear that adding job dummies serves to produce increased estimates of the returns to general experience. In general, the graphs plot familiar wage-experience profiles. However, the estimated returns to general experience between jobs in Table 3 and Figure 3 will almost certainly give upper-bound returns to general experience. In effect, we observe only successful job applicants and so, where adjustments to human capital are deemed to be required, then these would be expected typically to be positive increments for this group.

Note that the job dummies in Table 3 refer to wage changes. Figure 4 shows the dummy coefficients in the absence of the experience variables. Since the profiles are concave in Figure 3, we would expect that the between-job earnings changes regressed solely on the dummies - which represent mean differences in wages between jobs would become progressively smaller as more job changes take place. This is confirmed in by the plot in Figure 4. We also carried out an equivalent exercise in levels. Despite problems with biases in equation (5), given the unremoved fixed effects, we nevertheless estimated this equation directly. Again, we obtained significant concave profiles, though with generally smaller coefficients compared to equivalent results in Table 3. Job dummies in levels were generally significantly positive. Moreover, when we regressed wages only on the dummies - i.e. equivalent to the exercise in Figure 4 we found that that earnings increases diminish over jobs, again in line with the underlying concave wage profile. 
Table 3 Between-job earnings growth, 1994 (1958 - 1962 cohorts) (Dependent variable: $y_{0 j}-y_{o k}$ )

\begin{tabular}{|c|c|c|c|c|c|c|c|c|c|c|}
\hline & & & OLS estir & ates & & & & IV estim & $\mathrm{es} \S$ & \\
\hline & & $\begin{array}{l}\left(\mathbf{X}_{\mathbf{o j}^{-}}\right. \\
\left.\mathbf{X}_{\mathbf{o k}}\right) \\
\end{array}$ & $\begin{array}{l}\text { (Xoj- } \\
\text { Xok) }\end{array}$ & $\begin{array}{c}\text { (Xoj- } \\
\text { Xok) }{ }^{3} / 10 \\
\end{array}$ & $\begin{array}{c}\text { (Xoj- } \\
\text { Xok })^{4} / 100\end{array}$ & & $\begin{array}{l}\text { (Xoj- } \\
\text { Xok) }\end{array}$ & $\begin{array}{l}\text { (Xoj- } \\
\text { Xok })^{2}\end{array}$ & $\begin{array}{c}(\mathrm{Xoj}- \\
\text { Xok }^{3} / \mathbf{1 0}\end{array}$ & $\begin{array}{c}(\text { Xoj- } \\
\text { Xok })^{4} / 100 \\
\end{array}$ \\
\hline & & $\begin{array}{l}0.164 * \\
(0.034)\end{array}$ & $\begin{array}{c}-1.514 * \\
(0.619)\end{array}$ & $\begin{array}{c}0.826 \\
(0.449)\end{array}$ & $\begin{array}{l}-0.177 \\
(0.109)\end{array}$ & & $\begin{array}{l}0.541 * \\
(0.188)\end{array}$ & $\begin{array}{l}-8.946 * \\
(3.807)\end{array}$ & $\begin{array}{l}6.389 * \\
(2.851)\end{array}$ & $\begin{array}{c}-1.558 * \\
(0.705)\end{array}$ \\
\hline $\begin{array}{l}\text { Job } \\
\text { dummies }\end{array}$ & & & & & & & & & & \\
\hline Job 1 & $\begin{array}{l}-0.021 \\
(0.032)\end{array}$ & & & & & $\begin{array}{c}-0.170 * \\
(0.063)\end{array}$ & & & & \\
\hline Job 2 & $\begin{array}{c}0.038 \\
(0.024)\end{array}$ & & & & & $\begin{array}{c}-0.006 \\
(0.029)\end{array}$ & & & & \\
\hline Job 3 & $\begin{array}{c}0.052 * \\
(0.022)\end{array}$ & & & & & $\begin{array}{c}0.039 \\
(0.026)\end{array}$ & & & & \\
\hline Job 4 & $\begin{array}{c}-0.003 \\
(0.023)\end{array}$ & & & & & $\begin{array}{c}-0.029 \\
(0.028)\end{array}$ & & & & \\
\hline Job 5 & $\begin{array}{c}-0.038 \\
(0.030)\end{array}$ & & & & & $\begin{array}{c}-0.067 * \\
(0.034)\end{array}$ & & & & \\
\hline Job 6 & $\begin{array}{c}0.073 * \\
(0.033)\end{array}$ & & & & & $\begin{array}{c}0.062 \\
(0.038)\end{array}$ & & & & \\
\hline Job 7 & $\begin{array}{c}-0.042 \\
(0.050)\end{array}$ & & & & & $\begin{array}{c}-0.043 \\
(0.055)\end{array}$ & & & & \\
\hline Job 8 & $\begin{array}{l}-0.052 \\
(0.083)\end{array}$ & & & & & $\begin{array}{c}-0.051 \\
(0.088)\end{array}$ & & & & \\
\hline Job 9 & $\begin{array}{c}0.079 \\
(0.112)\end{array}$ & & & & & $\begin{array}{c}0.225 \\
(0.141)\end{array}$ & & & & \\
\hline $\begin{array}{l}\text { Without } \\
\text { Dummies }\end{array}$ & & $\begin{array}{c}0.141 * \\
(0.030)\end{array}$ & $\begin{array}{c}-1.108 \\
(0.579)\end{array}$ & $\begin{array}{c}0.545 \\
(0.425)\end{array}$ & $\begin{array}{c}-0.111 \\
(0.104)\end{array}$ & & $\begin{array}{l}0.375^{*} \\
(0.138)\end{array}$ & $\begin{array}{c}-5.750 * \\
(2.862)\end{array}$ & $\begin{array}{c}4.024 \\
(2.167)\end{array}$ & $\begin{array}{l}-0.972 \\
(0.538\end{array}$ \\
\hline
\end{tabular}

Notes: Standard errors in parentheses. Total sample consists of 930 individuals.

* Significant at 5\% level. § Both OLS and IV regressions include controls for 2-digit industries, sectors (private, central government, local government, public corporations), geographical regions, coverage by collective agreement, sectors. 
Figures 3: Returns to general experience (instrumental variable estimation)

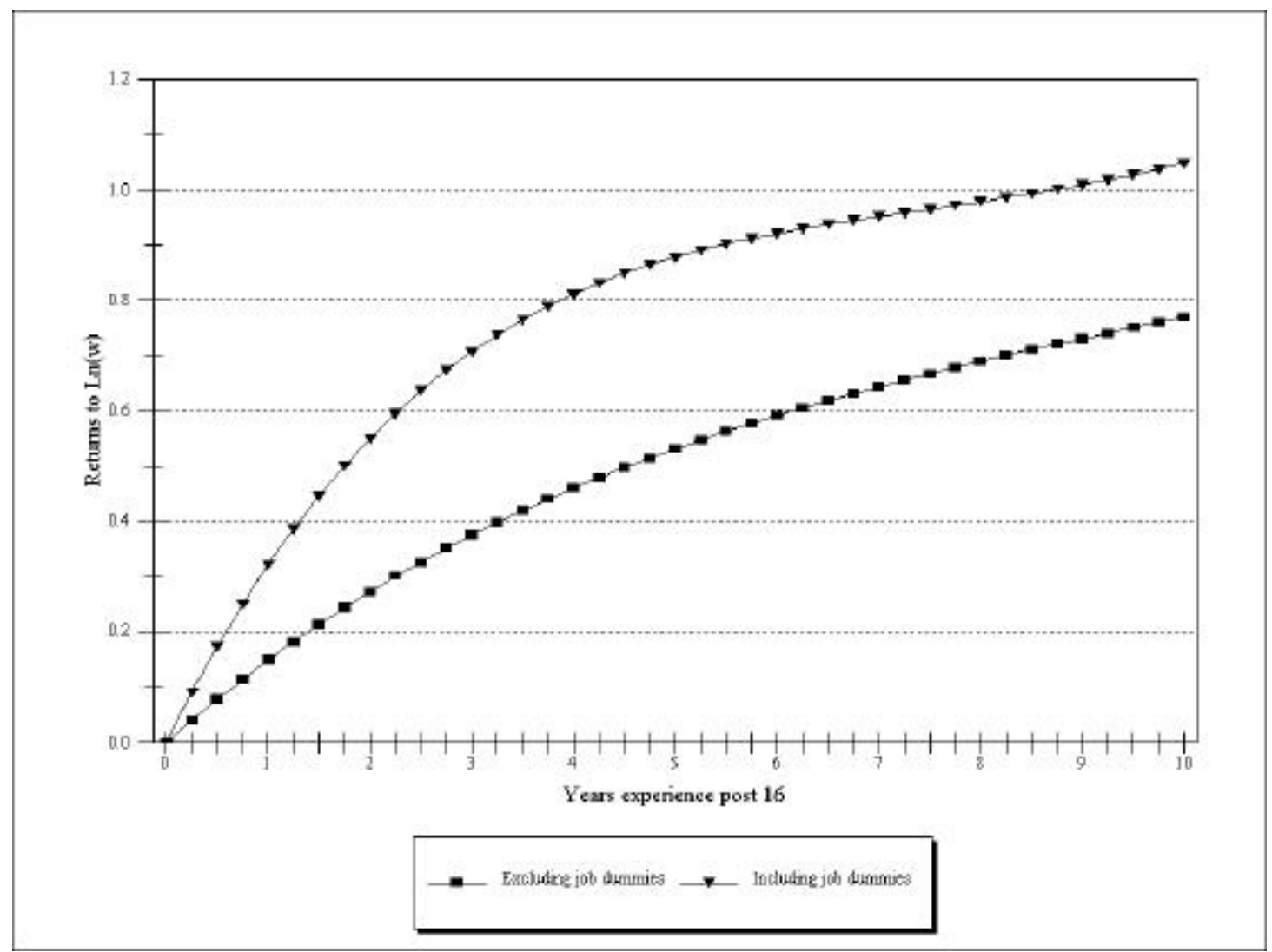

Figure 4: Returns to changing jobs (differenced)

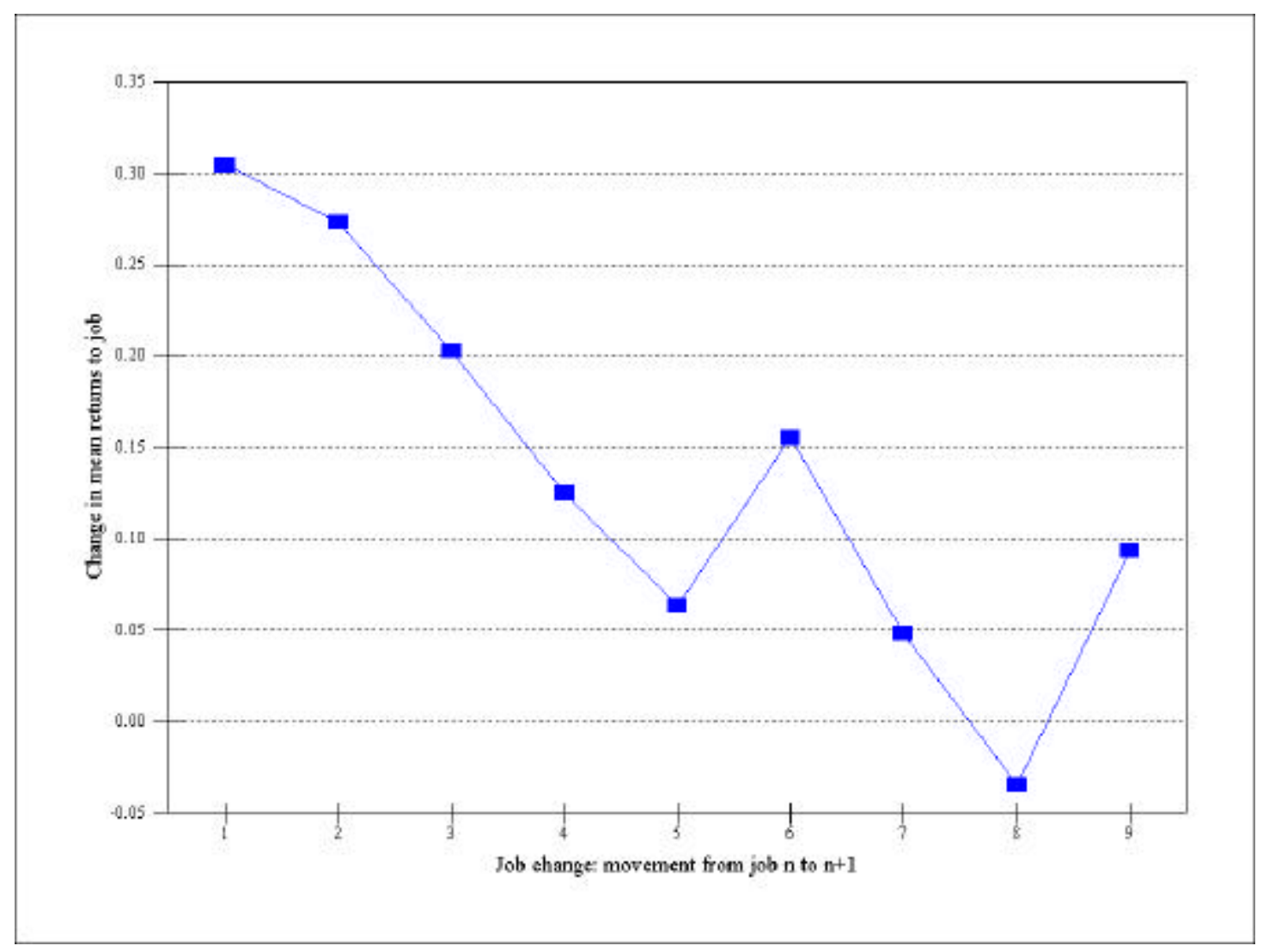




\section{Conclusions}

The empirical work in this study contains two special features. First, we record individual job changes whether they occur within or between firms. Second, we allow returns to the accumulation of within-job experience to vary over jobs.

Against this background, we question a core formulation that occurs in the large majority of papers on earnings-experience profiles. Thus, we argue against, and we find no support for, the view that the evaluation of general labour market experience is undertaken on a continual basis over an individual's working lifetime. Rather, wage setting within a given job is tenure-based, in that is it is predicated on performance in that job alone. In this event, job tenure measures general and specific returns on-thejob. Within-job returns are job-specific even if the acquired human capital is not. Under these circumstances, it would appear to be meaningless to attempt to separate returns to general and specific human capital.

However, while tenure captures the accumulation of intra-firm general human capital, we argue that the worth of such capital is also evaluated at the start of a new job. At the job selection stage, a retrospective assessment of general experience is made and, possibly, between-job wage adjustments undertaken where it is deemed that an individual has deviated from their "true" position on their career-path profile. Our between-job findings are consistent with this view. 


\section{References}

Dustmann, C., C Meghir, 1998, Wages, experience, and seniority, University College London, (mimeo).

Murphy, K.M., Welch, F, 1990, Empirical age-earnings profiles, Journal of Labor Economics, 8, 203-29.

Rosenbaum, J E, 1979, Tournament mobility: career patterns in a corporation, Administrative Science Quarterly, 24, 220-41.

Topel, R H, 1991, Specific capital, mobility, and wages: wages rise with seniority, Journal of Political Economy, 99, 145-76. 